\title{
Time, change, and sociocultural communication: A chronemic perspective
}

\author{
Thomas J. Bruneau \\ Radford University, Professor Emeritus in Communication \\ 263 Sowers Mill Dam Road, Riner, Virginia 24149, U.S.A. \\ e-mail: tbruneau@radford.edu
}

\begin{abstract}
The temporal orientations of any sociocultural grouping are major factors comprising its central identity. The manner in which the past (memories), the present (perception), and the future (anticipation/expectation) are commonly articulated also concern cultural identity. The identity of a cultural group is altered by developmental changes in time keeping and related objective, scientific temporalities.

Three modes of temporality, objective, narrative, and transcendental, congruent with different kinds of brain processes, are common throughout our planet. Objective temporality tends to alter and replace traditional narrative and transcendental (spiritual) time, timing, and tempos. Objective temporality is concerned with what is transitory, modern and "progressive". Objective time is not a traditional form of cultural time; it is a derived Westernized scientific imposition, rather than any cultural formation. This essay develops a new conception of how semiosis occurs. All information is essentially rhythmic, transduced through sensory systems as signals in a space-time domain, but deposited for use into a spectral thermodynamic domain in the human cortex.

A "chronemic" perspective, (temporality as it is based in semiotic processes related to human communication) is assumed throughout. Such a perspective appears to be somewhat novel in both communication and semiotic studies.
\end{abstract}




\section{Introduction}

Time study is a very important area of inquiry. All communicative behavior has an underlying temporality, as time in its many forms is central to human beings and their lives. The temporal transformations of the globe concern change, rates of change, and kinds of change as well as adaptations or resistances to change. Change is basically a temporal notion concerned with brain processes. What is new to a person within any sociocultural contact situation is what his or her brain will reject or acquire. Certain aspects of brain studies are included under another title to outline a new way to understand perception or semiosis.

It is quite clear that each sociocultural collective can be characterized as having a distinct psychological time configuration in terms of the relationships between their pasts, their presents, and their futures. These differences, as well as several other very important traditional temporal processes, have not been adequately addressed in semiotic and communication theory studies. Each sociocultural grouping exhibits unique temporal signals, symbols, beliefs, attitudes, values, and motives (Bruneau 1977, 1987, 1988, 1996). Time study requires interdisciplinary focus as well as a focus on neglected historical texts. The study of time is ripe for developing new communication theory.

Chronemics concerns the study of human temporality as it is semiotically communicative. This study includes many levels of human experience and not merely how people objectify, categorize, and thingify time keeping. Human processes are deeply embedded as temporalities. All genetic, biological, perceptual, psychological, social, or cultural processes show, indeed, that we are homo temporalis (Bradley 1973). Throughout the years, a few studies have been presented or published covering many areas of temporality in an attempt to build a "chronemics" (Bruneau 1973, 1974, 1977, 1979a, 1979b, 1985, 1987, 1988, 1990, 1996). Hall developed early ideas about time studies and was highly influential in the development of time and communication studies (Hall 1952, 1960, 1966, 1983).

The literature on human time experiencing is voluminous and complex. The appearance of Julius T. Fraser's anthology, The Voices of Time (1966) and the publication of the proceedings of a conference sponsored by the New York Academy of Sciences in 1966, Interdisciplinary Perspectives of Time (Fischer 1967), initiated a generative 
impetus toward the study of human time experiences. These early thrusts provided the impetus for the creation of the International Society for the Study of Time. This writer has been a member of this group for the past 30 years. In 1991, the journal Time \& Society (1991-) appeared, focusing on social aspects of temporality. Recently, KronoScope: Journal for the Study of Time (2001-) was launched by the International Society for the Study of Time. A close examination of the interdisciplinary time literature, however, shows that some scholars in philosophy, physics, biology, and some other fields of study have dedicated themselves to time study and its mysteries long before the advent of these publications.

This essay attempts to bring together some concepts of time experiencing study as they could possibly be applied to semiotic and sociocultural communication. In turn, we will consider the need for and the neglect of human time study, the steady spread or diffusion of objective time keeping and its limiting assumptions, implications of recent brain studies, and some considerations about the dynamics of communicative entrainments (adjusting to strangeness) and synchronicity (sharing similar tempos).

\section{The need for and the importance of time study}

While a "chronemics" of human communication is occasionally mentioned in the communication studies literature about time as a nonverbal characteristic, it is often only related to a few popular ideas such as being on time, waiting, being late, monochronic as opposed to polychronic time (Hall 1960, 1966), and punctuation (Watzlawick, Beavin, and Jackson 1967). However, there has not been any sustained or serious focus on human temporality in communication or semiotic studies. I have often claimed that it is not space that is the hidden dimension of human communication (Hall 1966), but it is time that is hidden and is a major aspect of all areas of semiotic or nonverbal communication. Time, timing, and tempo actually seem to integrate areas of nonverbal communication not previously considered related to time, i.e., proxemics, kinesics, paralinguistics, haptics, oculesics, olfaction, and gustation. All are essentially temporally wave-based, rhythmic, and neural semiotic processes. 
In the past, statements were collected about the need to study time in human conduct, (see below). Around 1990, these statements came to a halt and an increase in the study of time and human relations began. The last significant statement about the need for social and psychological time study, that I am familiar with, is that of McGrath and Kelly:

Although time has been given considerable attention in philosophy, and in the physical and biological sciences, it has been given remarkably little attention in the social and behavioral sciences in general, and in psychology and social psychology in particular. In mainstream social psychology, time has virtually been ignored. (McGrath, Kelly 1992: 399-400)

Some scholars in their fields of study begin the study of temporality by discovering its all-pervasive importance and, then, realize that they are exploring and charting exciting new territories. The attestations to the importance of time studies have not been heeded to-date in communication or semiotic studies, but these attestations spanning several decades are important to understanding the value of incorporating time study in human contact studies. These statements below are important because they not only show a continuing lack of scholarly focus, but a continual and present need for time study in human relations.

Long ago, Frank stated that,

Perhaps no area is more in need of exploration for its temporal implications than the field of human conduct and none offers more promise of fruitful reward for imaginative speculation, since all human conduct [...] is conditioned by $[\ldots]$ the time perspectives of the individual and his culture $[\ldots]$. (Frank 1939: 294)

Innis (1952: 57) observed that, "A neglect of the time problem implies a lack of interest in theoretical problems". Hall stated that, "Americans are perplexed by people who [operate without clock time] [...] we can no longer neglect other conceptions of reality" (Hall 1959: 138). Polak (1961: 138), in discussing variable future perspectives, said, "Each cultural epoch has its own unique fitting images of the future [...] certain types of [people] hold certain types of visions".

The sociologist Moore (1963), stressed the need for communicative and social time study four decades ago: 
Conceptions of time are distinctly variable from one culture to another. Yet the ordering of social behavior has received only sporadic or intermittent attention by the sciences dealing with man [...] The focus on time as a central feature of order and sequence $[\ldots]$ is so minimally developed that no one has even invented a name for a science of the temporal dimensions of social life. (Moore 1963: 5)

Doob (1971: 63) noted that, "All aspects of time that are standardized within a society - the modal information, standards, perspectives may be utilized as clues to understanding the significance of many forms of behavior". According to Cohen (1971: 153-154), "A scientific world picture with pretensions to comprehensiveness cannot refuse to reckon $[\ldots]$ with the experience of time". Maxwell observed that:

Anthropological theorizing about time perspectives and time-reckoning
schemes is still in the formative stage. The cross-cultural study of time has
not yet been given a name, nor have 'schools' of thought about the subject
emerged within the discipline. No anthropologist is known as a specialist in
time studies. (Maxwell 1972: 47-48)

Fisher (1978: 79-80), a communication theorist, commented that, "Time is, without doubt, one of the most crucial, yet most neglected variables of communication [...] [a] failure or unwillingness or inability to deal with the complexity of time, its varied aspects and dimensions". The social temporalist, Zerubavel, noted that, "While time is definitely one of the most central dimensions of the social world, it has so far been relatively neglected by sociologists [...] as a topic in its own right", (1981: ix; also see, Zerubavel 1979, 2003). In his revolutionary book, The Dance of Life: The Other Dimension of Time, Hall (1983: 184) stated that, "In this book, I have done my best to sketch the outlines of what will someday be an active, important major field of study, with significance to everybody". However, Hall's book on time has never gained any import in communication studies, as did his previous texts, and it is seldom cited by communication scholars. McGrath and Kelly (1986: v) asserted that, "The study of time at the social-psychological level is important. It is relatively uncharted area, with new ideas awaiting researchers at every turn. It is a topical area too long neglected. And, we believe, it will be even more important in the future." Maines lamented the scarcity of temporal focus in sociological theory: 
To purport to engage in an act of sociological inquiry is to commit oneself to the investigation of temporality [...] it is a basic mechanism through which social acts, organizations, institutions, cultures, and social structures exist and operate $[\ldots]$ there can be no genuine sociological theory [or semiotic and communication theory] that does not contain an underlying theory of temporality. (Maines 1987: 303)

What is amazing about all of these important calls for consideration of time study in the semiotics of interpersonal, social, and cultural communication contexts, is that few of them have been heeded at this date and a relative lack of focus on human temporality currently continues in these area studies.

It is not just the idea that time study is terribly complex; it is also a matter of assumptive neglect. The neglect assumes that: time is what a clock does; personal, social, and cultural dimensions of time are not real or valid; scientific uses of objective time are valid and natural to human living. However, Priestly observed that Westerners "hypostatize" time, "[...] to give actual existence to a concept [process, act, event, etc.] abstracted from our experience of succession" (1964: 53). It is typical of English and other Northern European languages to objectify and spatialize reality, to thingify. Word frequency counts find the words "is," "it" and "thing" to be some of the most used words in English. So, we often say "What time is it?" instead of saying "What is time?"

Our linguistic concepts about tense and syntactic systems (not to mention punctuation and juncture) impose a bias toward the objectification of time as spatial. When we use prepositions that imply temporal meanings, such as when we say, "at this point in time," "across time," "change over time," "ahead of time," "behind time," for example, we assume that they are small and simple words. However, these small and seemingly simple prepositional words bring into being a vast host of semantic and epistemological assumptions, (see Bree, Feddag, and Pratt 1993) for a more elaborate discussion of time and prepositions). These assumptions, for instance, are inherent in diffusion theory (how innovations are filtered and flow from supposedly progressive societies to less progressive ones) as outlined by Rogers (1995). Most communication scholars take only a scientific, objective time approach to their studies. But, in doing so, omit time as highly variable. The position here is that, instead of objectifying time, we should consider "change" as being an important definition of time. 
Our definition here is that change is equated with temporal variability. Time expands and contracts, necessarily, as a very basic human condition necessary to brain processes as will be shown under another heading.

More change or novelty as information means that time is experienced as going faster, the less change, the more time seems to drag in reference to clock time. Time varies with the speed, amount and complexity of information volume, a ratio of deja vue (already seen) and jamais vue (novel or new) information. "In-formation" means "formation within," and this definition has consequences in how we understand the importance of brain studies. It is also well known that novelty produces highly attentive states, making one's time appear to flow faster, while boring information makes one's personal time appear to drag. An exciting lecture seems to move the hands of a wall clock faster, while a highly boring lecture seems to develop a lethargic or frozen clock. Also, the Law of Janet can be understood as follows: how long a moment is, is inversely proportional to the length of life already lived. So, to very young children, time seems to drag, while elderly persons feel that time is flying by. This condition concerns the amount of oxygenated blood flowing to the main cortex and the lowering of brain temperature as people age. If we equate change with time, then to speak of "change over time" can seem ridiculous, even if it is a hallmark of science. It is not very well understood that scientific methodologies are often deeply assumptive about human temporality.

Objective forms of temporality current in diffusion, developmental, and sociocultural concepts concern time keeping and timetables (daily timing and calendrical scheduling). Sociocultural kinds of temporality, however, concern how people change, resist change, adapt to change, expand and contract the present, enact memories, and imagine any futurity.

All sociocultural time concerns subjective temporalities, the rhythms of social interaction, as well as psychic temporal orientations. Personal time concerns the unique temporalities of each individual (Bruneau 1977, 1985, 1988, 1989, 1996). All of these temporal distinctions are implied in any concern with diffusions of novelties across cultures as well as most developmental and sociocultural communication contacts. While there are marginalized people in every sociocultural grouping, most individual tempos often reflect those 
exhibited in one's primary reference groups. There are, however, common temporal norm violations and problems.

The notion of "time" is often assumed in technologically advanced societies to be what clocks and calendars and their extensions do. It will be argued here that all technologies, especially those based in media transmissions, are merely extensions of clock time, which is the basic medium of all technological media. Yet, tremendous numbers of people spread throughout the globe do not wear watches on their wrists. Investing money into the clock-making industry is still a good idea. Clocks, calendars, and time zones actually are not what time is; they tend to eliminate natural human time, the subjective temporality of individuals and cultural groupings. This is especially important in understanding those global groupings that can be conceived as "traditional". To assume that the clock is time is common and necessarily convenient to the evolution and diffusion of Western scientific objectivity and lineal reality parading as "modern progression" globally, a growing linearity. The oldest and most persistent "innovation" in a global context is that of objective time related to timekeeping assumptions. An excellent reference on the "semiotics of wristwatches" is an article by (Freake 1995). However, a huge literature exists on the concepts of "time keeping".

\section{Objective, scientific, and technical time}

The clock is the master machine/device of all scientific and technological developments. McLuhan (1964: 143) once observed that, "Clocks are mechanical [or electronic] media that transform tasks and create new work and wealth by accelerating the pace of human association". Almost all of our modern communication technologies concern faster and faster and more and more contacts between people in both their work and private lives. Gonseth commented that:

One speaks as if [...] the indispensable observation clocks were entirely made [...] One seems to forget that this clock has not dropped out of the skies, but that it had to be put together, and that this could be done by an audacious anticipation, by laying down as correct the very laws of mechanics that it would serve to submit to observations. (Gonseth 1972: 289-290) 
Mumford noted that, "The clock [...] is the key machine of the industrial [and the technological and electronic] age" (1962: 14) and "The first characteristic of modern machine civilization is its temporal regularity" (1962: 269). An early alarmist, Wright (1958: 7), noted that, "This is a history of an increasing, unchecked, and now intolerable chronarchy [...]. Let chronarchy, then, be not merely "rule by time', but 'regimentation of man by timekeeping"'.

Clocks are created to produce lineally assumed equal intervals in a cyclic sequentiality, (the Newtonian equitable flow without reference to anything else), which in turn helps people to regularize and coordinate divergent personal and sociocultural rhythms. Modern, socalled progressive societies would collapse without a common time keeping. But, when Einstein was asked for a simple definition of "relativity", he said, "When you sit with a pretty girl for an hour it seems like a minute; but when you are on a "hot seat" for a minute it feels like an hour. That's relativity" (Kugelmass 1967: vi). Actually, Einstein was really making a sexual comment about highly attentive states as contrasted with physical heat upon biological processes. Actually, he often saw relativity in terms of biological time, rather than the time of physics. His viewpoint was that personal time, or what he referred to as "I-time," cannot be measured. But, increasingly, biological rhythms are measurable as noted in the increasing study of chronogenetics and chronobiology. Biological needs become drives, if not satisfied. Biological needs create biologic drives that alter both the expansion and the contraction of momentary experience. All biological needs and processes have temporal variations, including heart and breathing rates related to semiotic interactions. Much more study of sociobiological processes should yield important insights for semiotic studies.

Communication theorists and researchers have not dealt with temporality as complex processes, neglecting especially the idea of human relativity. We will refer to relative temporality as "narrative consciousness" (see, for reference to time and narrative, Ricoeur 1984, $1985,1888)$. To neglect relativity is to live in an objective world. This can be troubling because it prevents new thinking about human interactions. Clocks, timing devices, and objective time constructions can occasionally be coordinate with the sociocultural rhythms of the young, the elderly, and most of the world's population who are not yet on the Internet, but frankly, such coordination is rare. 
The British psychologist, John Cohen (1966: 252) noted that, “[...] it is conceivable that our reliance on watches and other artificial aids [to timekeeping] has led to an atrophy of our sense of time". The identity of many people concerns how they measure up to a clock or clocklike "pacers", a "clock insanity" can develop (Bruneau 1974). Much of Westernized public interactions take place in an objective time angst or with quick glances at clocks and objective time references of many kinds. Pointing to the clock as time itself, as an independent, but constant variable (a contradiction, because there are no constancies in a human processual world) is the first resistance to temporality as a complex dependent variable. Startings and stoppings, beginnings and endings, befores and afters, zeros and ones, etc., are elusively complex and assumptively fixated only as objective time impositions and assertions. However, these tend to regularize our temporal perceptions and estimates. As Berg stated, "If the aim pursued by the clock would be realized, there would no longer be time [as subjective or personal]. For time is the inequality of dimensions [...]. An honest clock is thoroughly complete in its attempt to eliminate time", (Berg 1970: 111-112). Further, as Whitrow (1972: 27) cogently observed, "The mechanization of time helped to disassociate time from human events and helped to perpetuate a belief in an independent world of science".

John Dewey said:

Individuality conceived as a temporal development involves uncertainty, indeterminacy, or contingency... The mystery of time is [...] the mystery of the existence of real individuals [...]. Genuine time [...] is all one with the existence of individuals as individuals, with the creative, with the occurrence of unpredictable novelties [or changes]. (Dewey 1940: 204-206)

Personal, social, and psychological temporalities, then, are genuine kinds of time. Clocks do not measure time; they measure assumed empty spaces, and actually tend to help spatialize human rhythms and processes as statically invisible. What seems to have escaped the purview of diffusion of innovation, developmental, and sociocultural communication theorists is the greatest diffusion of innovation ever on the globe: the slow and persistent diffusion of Western forms of objective time. This global innovation has been increasingly spreading a different kind of temporality for several hundred years. Objective time is in the media, the channels of TV, the satellites, the computers, and all forms of new technology. These common devices of most 
technologically developed nations are not used by the great majority of the world's population. When peoples from various cultures do come to use these devices, they change their customary cultural acts, events, occasions, etc. Technological and objective temporalities tend to significantly alter sociocultural rhythms and tempo.

It was said previously that diffusion theory concerns how new ideas and products are accepted or rejected in different global regions by individuals and their groups. Diffusion theory appears to be epistemologically consistent in the adoption of a linear progression model as the very basis of its theoretical assumptions (Rogers 1962, 1983, 1995; Rogers, Shoemaker 1971; Rogers, Kincaid 1981). From a Western viewpoint for the purposes of research, for accountability in terms of diffusion rates, for S-curve production, for the success of a diffusion (novelty or change), and for the need to assess overall results, such a linear approach seems natural and justified, if one values objective temporality. After all, corporations and governmental agencies expect to know as much as possible about efficiency as well as on-going success and knowledge of results for difficult and expensive efforts.

It is understood here that such a linear, objective time view, when diffusions flow into various sociocultural collectives, can and does have indigenous sociocultural time resistances and even hostility. These resistances, according to Rogers, are important. Rogers noted that, "Until we study resistances, they cannot successfully be overcome. So, diffusion of innovation scholars should devote more attention to studying resistances to innovations" (Singhal, Law 1997: 43). In selecting and planning for innovation acceptance across sociocultural boundaries, it should be noted that temporal compatibility and predictability (futurity) within a traditional sociocultural collective must be considered as major factors as resistances. As Rogers aptly noted in an interview, "It is one thing to study an innovation that has diffused after it has done so. It is much more difficult to predict its diffusion" (Singhal, Law 1997: 43). Such an accurate prediction centers on further understanding of the neglected temporal differences, the basic human rhythms, of target sociocultural audiences. 


\section{Sociocultural rhythms (cultural time)}

Cultural time concerns the unique and characteristic temporal environments of particular sociocultural groupings great and small, formal and informal. Each traditional sociocultural collective develops a unique style of temporality. The rhythms of everyday life, of language, of communicative interaction, of nature, the rhythms created in people built environments, and all nonverbal or semiotic behaviors are built upon genetically and metabolically driven biological rhythms (Bruneau, 1980, 1985, 1987, 1988, 1989, 1995b, 1996, 1997). The position here is that all semiotic information is rhythmically-based; light waves, sound waves, pressure waves, molecular waves, and chemical waves aid in the creation of both individual and cultural time. Sociocultural rhythms, from birth to death, are inducted into each and every individual, into his or her everyday life, with rhythms arising from one's collective and its many rhythmicities. Sociocultural time also concerns how a collective develops a past, a present, and a future as its psychological time shared by its members. Authentic time is how change changes, how dynamic here-and-now processes vary, how there are kinds and rates of change, and how authentic human time concerns the unique and divergent temporalities of individuals interacting rhythmically within sociocultural collectives.

All cultural groups tend to develop unique, indigenous codifications of a naturalistic time (sunsets, siestas, when the birds first sing in the morning, when birds or fish return etc.) not necessary to clocks. Time reckoning by celestial bodies, the indigenous accounting of the rhythms of nature and the seasons, and biological events have evolved for many, many thousands of years where people have not needed a clock to tell them that they are hungry or that it is time to change their wakefulness. The manner in which the past is codified in language, in nonverbal communication, in rituals, in ceremonies, in dances, in songs, etc., varies considerably from one cultural group to another. There are many kinds of "histories", not simply one history as defined by Western societies. Mythic history is common throughout the globe and Western history is no exception. Each religious grouping, too, has its past codified as a permanent exactitude leading to a happy or sad hereafter. Quests for permanency are commonly, but differentially, balanced with the processual flight of impermanence everywhere. 
It is not possible here to fully discuss sociocultural rhythmicity. However, three classical scholars of time and sociocultural change seem to nicely summarize what should be minimally said. Leonard Doob (1971: 49-60) outlined a series of propositions about temporality in social and cultural perspectives. Some of them are:

Periodic changes in the external milieu invariably and everywhere provide the potential for acquiring knowledge concerning the duration and succession of intervals and for the arousal of temporal motives. (49)

All persons everywhere are oriented periodically toward the past, the present, and the future. (52)

Modally within the person, within significant groups, and within the society as a whole, one temporal perspective rather than another is likely to be facilitated. (54)

The modal temporal perspective of a society reflects and affects a modal philosophy of values pertaining to other behavior. (56)

The stronger the temporal perspective, the weaker the orientation in other directions. (59)

Each society provides appropriate information for passing temporal judgments. (Doob 1971: 60)

Lomax offers us one of the keenest and distinct descriptions of cultural rhythmicity:

Rhythm is, after all, a prime mover in social relations. Rhythmic patterns facilitate the co-activity of groups and aid their members in coordinating energies and resources in work, nurturance, defense, social discourse, rites of passage, interchange of information, and, above all, expressive acts. The important role of rhythms in group behavior suggests that we can view the rhythmic aspects of communication as essentially social in nature - a system that binds individuals together into effective groups and links groups into communities and polities. Each such "rhythmic style", passed on generationally, shapes many aspects of each cultural tradition. (Lomax 1982: 149)

Semiotic, linguistic, built environment, and social rhythms are inducted or channeled into the brains of individuals (see below). Fraisse (1963) describes a process of "rhythmic induction" whereby energy wave fields as rhythms are acquired by individuals developmentally. Holonomic brain theory, below, describes this process more thoroughly. Thus, the individual acquires the sociocultural rhythms of his or her social order for better or for worse. Fraisse (1963: 40-41) elegantly describes this process: "Rhythmic induction permits living 
creatures to turn reflex reactions into reactions of anticipation [...]. The existence of organic rhythms induced by periodic variations in the environment has particular psychological consequences for [people]. They provide [them] with an internal clock".

Induction concerns, of course, how brain operations and systems of perception or semiosis are temporal processes in interactions between nowness (attentiveness, presentness), memories, and forebrain processes. These temporal brain systems are analogously approximate to all environmental rhythms and simply codify and, then, regulate our adaptation to them.

\section{Brain differences across cultures}

It is only possible here to briefly sketch some ideas about brain differences and the reader is referred elsewhere for further information (Pribram 1971, 1986, 1990a, 1990b, 1991, 1993, 1994, 1999, 2003, 2004; Bradley, Pribram 1995; Pribram, Bradley 1998; Bruneau 1985, 1988, 1989, 1995a, 1997).

Holonomic brain theory and research (Pribram 1990b, 1991, 1999, 2004) and "connectionist" brain theory (below), when integrated, help to explain why brains differ from one individual or cultural grouping to another. Holonomic brain theory deals with how rhythmic and wave-based energy fields in any person's various environs are converted and transduced or channeled as signalic to brain area cortices. Signalic (semiotic) conductions, as nerve impulses in the regular "space-time domain", are then slowed, converted, and synapically spread as thermodynamic transformational patternings in an analogic, algebraic, "spectral domain" in the main cortex and several others thinly covering some mid-brain organs.

Holonomic brain theory concerns how extremely complex, dynamic and vibrant lakes of energy or holoscapes (holograms if measured) interact with other such "configurations". Each cortical neuron is connected dendritically with approximately ten thousand other neurons. It is in the many millions of synaptic connections, working in aggregate, that we find the brain's re-presentation of any semiotic signal. The description concerns thermodynamic transformations coupled with brain circuitry connecting various brain areas and medial brain organs. Within synapses are microscopic structures called 
"microtubuals". Within the microtubuals are neurochemical processes that create photon emissions (Jibu et al. 1994, 1996; Pribram 1990a, 1991, 1993, 1994, 1999, 2003, 2004). Thus, the main cortex of the brain concerns complex thermodynamics, but the nature of meanings and consciousness concern many puzzles as to how thermodynamic photon emissions or cortical "light" relate to meanings. How thermodynamic energy is related to systems of consciousness is highly speculative at this juncture. But, a kind of superconductivity has been speculated about "thinking". It is also important to consider that "minding" concerns in-formation or formation within, but "matter" or immediate reality concerns ex-formation, (Pribram 2004). The main cortex is connected to mid-brain organs and other sub-cortical structures by built in brain pathways or circuitry. We will discuss some of these important pathways below under the subtitle "Three brain axes".

Connectionist brain theory develops the idea that the "mind" is not initially in the brain, but is carried within the energy-based rhythms (semiotics) of any individual's natural, people built, and sociocultural environs to be acquired (see, for example, Fischer 1989, 1990, 1992, 1996; Freeman 1995; Varela, Thompson, Rosch 1993). The individual brain maps upon the messages (the mind) of its sociocultural rhythmic environments. So, perceptions as rhythmicities (semiosis) from the sociocultural collective are transduced or impinged upon individual brains within an initially limited freedom of choice. But, each individual has a unique genetic and biological thrust against its environmental rhythmic configurations and restraints. Each child projects against its surrounds differentially and developmentally increases his or her projective, top-down brain axis. The brain "represents" (makes present again) the rhythms of energy patterning previously acquired through usage (repetition and redundancy are very important). The stored habitual energy analogically maps onto rhythmic stimuli present in the three-dimensional world of matter or ex-formation (Pribram 2004). The mapping is never exact and creates individual and unique experience. It is "in-formation", or "formation within" which is compared to new experiences as cyclic (in and out) perception. It is recursivity and inhibition that concerns regularity and one's re-ality (all again) or stable environment. Novelty or learning concerns attending to rhythmicities that vary from our individual stabilities or exformations, "matter". 
The new paradigm is: the brain is the "medium", the mind is the "message", and communication is the "means". The brain is the medium of all other media. This obvious fact is not sufficiently appreciated for its revolutionary import. Most scholars seem to think that what carries a message is its media. But, this is a terrible assumption because it is the brain that processes information, media devices only transmit information, but only the brain processes formations within. Cybernetic developments are making inroads into these processes. The brain is central to all information. How the brain is constructed (self-organizing theory) is similar in every culture and person, but males and females have brain chemical, biological, anatomical, and consequent usage pattern tropism differences that can account for many sociocultural gendered communicative differences (Bruneau 1995a, 1995b, 1997, 2000; LeVay 1993; Loy 1986; O'Keefe, Nadel 1978).

Every child is born into some kind of sociocultural collective and is exposed or not exposed to other collectives. It is the collective (the mind or messages) that develops sociocultural rhythms that are channeled into individual brains; the rhythmicities are transduced through sensory systems and hippocampal screenings that sort out novelty from habituation. This process is described further below in considering three brain axes. From a connectionist brain perspective, the "mind" is carried in the sociocultural collective and deposited purposively or haphazardly into individual brains. It is human communication, semiotic contact and exchange, that provide the means whereby any individual becomes a member of a particular mind already existing in his or her environmental surrounds. The mind is acquired however haphazardly or efficiently within the restraints or opportunities afforded in every sociocultural collective.

Brain differences across cultural groupings are real and involve how energy is habitually and repetitively patterned into the brains of its members with the inevitable presence of signalic noise, as well as forgetting. It is complex temporal regularities or patternings that create brain differences from one sociocultural collective and one individual to another. 


\section{Three brain axes}

Brain differences not only involve the regularized rhythms to which persons are exposed, but also to the habitual interactions of three major brain axes. The functions of these axes and their stylized usages and interdependencies create different kinds of consciousness from culture to culture. These major axes dynamically intersect and create a person's consciousness within his or her sociocultural collective. These axes can be described as: "bottom-up — top-down; "left—right"; and, "back-front" (Pribram 1998, 1999, 2003).

"Bottom-up" deals with how all energy is wave-based and is "input" or formation within the brain. It concerns all stimuli from our senses and our soma transduced and conducted to the brain. The "topdown" axis concerns how the brain projects previous habituations upon bottom-up processes to create interfaces. We project upon receptions; this is the essence of semiosis. It is an "in and out" process, rather than an "in or out" process, as behaviorists would have it in their brainless endeavors. Thermodynamic energy within the brain from previously collected and stored rhythms is projected upon and interfaced with energy being transduced. The hippocampus helps to map and screen information, allowing novelties to accend to the cortex and ignoring habituations (O'Keefe, Nadel 1979; Isaacson, Pribram 1986). We imagine reality to be only external to us and stimulusresponse theory and behaviorist interpretations have created this mythology. Behaviorism study has not included brain study, but a future neurobehaviorism seem probable. All formation within is cyclically and recursively connected with current stimuli projected within the sociocultural collective. Some brain formations are detrimental to a person, some are liberating. Sociopathic rhythmicities are easily mapped upon brains to become problematic in any social or cultural grouping.

The "left-right" axis deals with processing information that is integrated between the two major hemispheres (Efron 1990). The richly myelinated corpus callosal and septal bridges between the hemispheres allow for extremely quick interactions and are not meant to separate the hemispheric processes, but to conjoin them. The left hemisphere is the objective, sequential, area of the brain. The left hemisphere does not usually act independently from the right hemisphere, but can do so in the processing of linear, ordinal, and 
sequential information. Most men seem to be often unable to sustain and process information well in the right hemisphere. The right hemisphere is the attitudinal, emotional, intuitive, and feeling area of the human brain. The right hemisphere concerns flow of experience, narrative, and analogically-based, emotive information processing. Men and women differ significantly on the integrations between the hemispheres and habitual usage patterning. Women have richer connections between the hemispheres and appear to be able to process emotional and intuitive information better than men (Bruneau 1995a, 1995b, 1997).

The "back-front" axis is as important as the "left-right" axis (Pribram 1998). The "back" concerns reference memory usage in the parietal areas and connects through mid-brain organs with the frontal lobes. So, the memory reference area of the brain (past) is connected to the frontal lobe areas (futurity), involving attentive readiness, expectation, prediction, forecasting, planning, and anticipatory forethought, etc.

The circuitry and structures of the mid-brain connect these axes to define a person's "re-ality" (all again) at any given moment (Bruneau 1988, 1989, 1995a, 1996, 1997, 2000). The rhythms of the natural and celestial environments are inducted into the brain along with the rhythmicities of the social and constructed environments. Many people in so-called "developed" countries have actually lost contact with the narratives of natural environments or these environments are completely ignored or have been or are being destroyed. Technological time is mainly left-brained and concerns objectivities processed in the left parietal lobe (back) and sequenced in the left frontoorbital lobe areas (front) as planned futurity. It concerns unitized sequentiality and is called "objective consciousness". It is generally egocentrically operational, logically or illogically so. It develops slowly in boys and is the reason why boys go over big waterfalls in small bad boats. Left brained sequential planning takes years to develop, but thinking "ahead" is an art form in great need of development through education. The development of the frontal lobes in long range planning is a recent phenomenon, developmentally and historically.

The right hemisphere processes attitudes, feelings, emotions and a flowing narrative of experiencing in conjunction with certain midbrained circuitry. It concerns empathic forethought and intuition; it is 
allocentrically (other-directed) construed and involves empathic feelings into others semiotically and thoughtfully (Bruneau 1988, 1989, 1995b, 1996, 1997, 2000). Most cultural groupings are still more narratively involved in familia and the collectively mapped mind; this concerns what can be called, narrative consciousness. It also includes metaphoric flow, aesthetics, poetics, life stories, and literary modes, etc. (Ricoeur 1984, 1985, 1988).

Modern technological media are mainly left-brained operationally, but can instigate narrative (e.g., words can create poetic, artistic, and metaphorical flow). Technological or objective time utilizes leftbrained unitizations and predicated sequentialities that are uncommon to the vast majority of the global populations. It is a Western kind of thinking and relating. Modern communication technologies are being rapidly diffused into groupings whose traditional members are based in narrative consciousness, but the children or grandchildren are into cyber worlds, thinking and behaving differently than their cultural groupings. This is an unappreciated aspect of the so-called, "digital divide", a mismatch in brain consciousness usage across sociocultural boundaries. Traditional sociocultural rhythms mainly concern habitually narrative and analogically based information processing (personal and social temporalities); technological time concerns objectivity, rationality, order, structure, etc. only infrequently practiced by older members of a sociocultural grouping. A number of avenues into time and cultural studies are reported by Bruneau (1979b, 1980, 1990, 1995b, 1997; Merriam 1983). Some of the more recent works that deal with the problems of objective time in contrast with traditional cultural or narrative time, for example, are: a study of the time of a northern Philippine community (Pertierra 1993); traditional Sicilian time (Morello 1997); forced exposure to Western time in traditional Japan (Ikuko 1997); time travel among the Crow (Barnes 2005).

\section{An energy-based model of human communication}

When a person enters another sociocultural grouping as a stranger, he or she is a novelty and the new sociocultural collective is a novelty to the person, a double novelty or double strangeness occurs. This increases the uncertainty and creates tension fields (dysrhythmia) as temporal differences become apparent. What happens, then, when 


\section{Thomas J. Bruneau}

people from objective consciousness groupings communicate with those from a narrative and/or a transcendental consciousness group?

We should understand that an "innovation" can be an object, a device, a product, an idea, or a new person in another person's regular sociocultural awareness. A person can be and often is an innovation, a novelty, a temporal strangeness. So, on the cover of Rogers' fourth edition of his Diffusion of Innovations text (1995), is a photograph of a drop of water that has created an innovation (waves flowing outwardly in ripples through the water medium (the sociocultural collective). Actually, this is a very credible, but simplified, model of what happens when a new input is accommodated in the human brain. We must understand that the human brain is what changes and must change in the world of differences across cultures. Let us examine how energy is involved.

Fourier, a French mathematician, visited North Africa on an expedition with Napoleon. Upon his visit he consulted with some Arab mathematicians. They showed Fourier how a pebble dropped into a pond created wave fronts that could be intersected with other wave fronts from other rocks dropped. It was shown that waves intersected, interacted. Also, waves could back propagate from the boundary shores and create more wave fronts. In holonomic brain theory, the boundary enfold distributions of holoscapes appear to be similarly constructed (Pribram 1991). So, in a field of thermodynamic wavelets intersecting, we can imagine analogically how holoscapes are created in the human brain. Every wave created can be traced back to its original force and velocity (stones hitting the water) at any intersect of the wave complex. This is a characteristic of holographic formation within.

Brain holoscapes are Fourier transformations, huge networks of brain aggregates working together in a spectral domain, a thermodynamic complexity (Pribram 1991). Every neuron in the cortex is connected simultaneously with an average of 10,000 other neurons through dendritic, synaptic connections. So, with a brain averaging something on the order of 80 billion cortical cells, with each cell connected to approximately 10,000 other cells, we can imagine a great complexity of holoscapes interconnecting exponentially. Holoscapes are algebraic representations of previous usage patterns of perception; these patterns of perceptions (habits of perceiving) are what each sociocultural interactant brings to a communication contact with 
strangers. So, what are mapped upon every human brain are kinds of wave-based information from perceptions within their rhythmic environments, their built, social and natural collectives. The acquired and active brain energy transformations are projected recursively and cyclically upon both new and old rhythms contained in the bottom-up stimuli from an individual's biological and sociological rhythmic surrounds.

Sociocultural contacts between strangers bring different holoscapes from culturally different people into the interaction as unknown or unresolved entrainment tensions, dysrhythmic interactions, hopefully with eventual attempts to synchronize with one another.

The hippocampus in connection with the human cortex creates a mapping function similar to what was previously said to be a blocking of the defunct reticular formation. So, the brain conserves its energy by screening out information that is old hat or already common. When a stimulus is new, an innovation, a different kind of person, a visitor to an unusual cultural group, this newness can be resisted, ignored, or accepted into new brain pattern imaging. When a new perception is accommodated and allowed to enter the human cortex, the cortex must be adjusted to allow the difference to be integrated. This is called "entrainment", or attempting to adjust to a new difference. Once the difference is adjusted and integrated, it can be called a synchronicity or dealt with as people being somewhat in "synch".

Brain patterns that are used over and over create more stable and less changeable holoscapic patterns or memories. Dogmatism, closedmindedness and rigidity of consciousness can negate new information attempts to create a restructuring of the holoscapic energy fields. This is what learning is all about. The "plasticity" or the ability to reconstruct brain patterns after injury or after habituation is important. Rigidity in perception implies that brains can be wired up in the sense that software becomes more like hardware. Deja vue information concerns habitual processing while jamais vue information concerns dishabituations (novelty). The challenge for any innovation or change across cultures is to first assess the habitual rhythmicities in a sociocultural collective and, then, to plan on how new rhythms can be projected into an already existing kinds of perceptual and psychological time, a stranger's temporal perception and consciousness.

Interestingly, Bradley and Pribram (1995) have attempted to connect the energy transformations in the brain with social communi- 


\section{Thomas J. Bruneau}

cation networks. They were trying to show that what is networked within brain transformations is reflected in networks of social rhythms with some congruence. Such a connection between the rhythms of society and the rhythms of a brain within that society is credible in a recursively cyclic model of perception. Pribram and Bradley (1998) have also attempted to connect brain processes with a hidden personal self (an "I") in contrast with an expressed public self (a "me").

All media is the medium of the brain. The brain is the medium of all communication, regardless of how information is transmitted. What else could be the medium of media? New technologies do not mediate brains and temporal differences across cultures. It is the other way around: brains mediate all technological media transmissions and these transmissions are integrated or not integrated in sociocultural communication transmissions. Any sociocultural communication problem must be understood as differences in brain activities, perceptual (non-verbal or semiotic) codes, and systems of consciousness. This is a basic and primary effort that is in great need of further support from semiotic and communication scholars.

\section{Summary}

It was shown that there is a need to include time study in sociocultural communication and semiotic study and that a neglect of time study has occurred. Sociocultural rhythms are combinations of objective and subjective temporalities. The more modern and technological a sociocultural collective, the more formalized are its objective time perspectives; the less modern and technological a sociocultural collective, the more that narrative forms of experiencing, of consciousness, and subjective temporalities will define the spatio-temporal characteristics of a grouping. It must be understood that some members of a collective operate within a spiritual or transcendental temporality (Bruneau 1988, 1989, 1995a). Transcendental kinds of consciousness are often extensions of narrative consciousness and utilize quasi-linear or nonlinear contemplative or meditative brain processes.

The temporal characteristics of a group are mapped upon and within the brains of its individuals. Holonomic brain theory and its integration with connectionist brain theory offer explanations about how people can reject or resist the adoption of the differences (no- 
velties) encountered in sociocultural as well as person to person communication. Differences between objective time and subjective time concern differences in temporal styles of consciousness. These differences have to do with the rhythms of innovations and the rhythms already mapped upon the societal mind and imposed upon or accepted by individuals. It is suggested that semiotic and communication theorists in diffusion, developmental, and sociocultural communication studies integrate temporal concepts into their thinking and research in future years.

\section{References}

Barnes, David E. 2005. Time travel among the Crow. KronoScope 5(1): 83-87.

Berg, J. H. van den 1970. Things: Four Metabletic Reflections. Pittsburg: Duquesne University Press.

Bradley, M. 1973. The Chronos Complex I. Toronto: Nelson, Foster, and Scott.

Bradley, Raymond T.; Pribram, Karl H. 1995. Communication and the stability of social collectives. Radford: Radford University, Center for Brain Research and Informational Sciences.

Bree, David S.; Feddag, Allel; Pratt, Ian 1993. Toward a formalization of the semantics of some temporal prepositions. Time \& Society 2(2): 219-240.

Bruneau, Thomas J. 1973. Communicative silences: Forms and functions. Journal of Communication 23(1): 17-46.

- 1974. Time and nonverbal communication. Journal of Popular Culture 8(3): 658-666.

- 1977. Chronemics: The study of time in human interaction. Journal of the Communication Association of the Pacific 7(1) 1-30.

- 1979a. Chronemics: Time and organizational communication. Journal of the Communication Association of the Pacific 7(1): 81-97.

1 This article is a revision of a paper presented at the Communication Congress of the Americas, "Time, cultural change, and intercultural communication", Lima, Peru, August 2006.

Acknowledgements. I am thankful to Dr. Karl Pribram who allowed me to audit three of his classes at the Center for Brain Research and Informational Sciences at Radford University in Virginia: Languages of the Brain (1996); Brain and Perception (1997); and, Brain and Conscious Experience (1998). Also, I am thankful to Dr. Pribram for developing and chairing several Appalachian Conferences on Behavioural Neurodynamics while he was at Radford University. I was fortunate to attend them. I am also thankful to a departed mentor, Dr. Roland Fischer, for his encouragement and guidance over the years. 


\section{Thomas J. Bruneau}

- 1979b. The time dimension in intercultural communication. In: Nimmo, Dan (ed.), Communication Yearbook, vol. 3. New Brunswick: Transaction Books.

- 1980. Theoretical perspectives on the temporal bases of intercultural communication. Journal of the Communication Association of the Pacific 9(1): 77-111.

- 1985. Silencing and stilling process: The creative and temporal bases of signs. Semiotica 56(3/4): 279-290.

- 1987. The structure of chronemics. In: Bagley, Thomas (ed.), Current Trends in Nonverbal Communication. Jonesboro: Arkansas State University, 95-120.

- 1988. Personal time and self-identity. In: Reale, Paola (ed.), Tempo E Identita. Milano: Franco Angeli, 102-115.

- 1989. The deep structure of intrapersonal communication processes. In: Roberts, Charles; Watson, Kittie (eds.), Intrapersonal Communication Processes: Original Essays. Scottsdale: Gorsuch Scarsbrick, 69-86.

- 1990. Chronemics: The study of time in human interaction. In: DeVito, Joseph A.; Hecht, Michael (eds.), The Nonverbal Communication Reader. Prospect Heights: Waveland Press, 301-311.

- 1995a. Contemplation: The art of intrapersonal communication. In: Aitken, Joan A.; Shedletsky, Leonard J. (eds.), Intrapersonal Communication Processes. Plymouth: Midnight Oil Press, 208-217.

- 1995b. Empathic intercultural communication: State of the art and future potential. Intercultural Studies: Journal of the Intercultural Institute. Kanda University of International Studies (Japan), 8: 1-24.

- 1996. Subjective time, social interaction, and personal identity. In: Mokros, Harmut B. (ed.), Interaction and Identity. (Information and Behavior, 5.) New Brunswick: Transaction Publishers, 97-115.

- 1997. Implications of recent brain studies for understanding problems of intercultural communication. Human Communication Studies. Communication Association of Japan, 15: 1-41.

- 2000. Peace communication: The ethics of caring across cultures. In: Samovar, Larry A; Porter, Richard E. (eds.), Intercultural Communication: A Reader. Belmont: Wadsworth, 9: 455-463.

Cohen, John 1966. Subjective time. In: Fraser, Julius T. (ed.), The Voices of Time. New York: Braziller, 257-275.

- 1971. Time in psychology. In: Zeman, Jiri (ed.), Time in Science and Philosophy. Prague: Czechoslovak Academy of Sciences.

Dewey, John 1940. Time and individuality. In: Hering, D.W. (ed.), Time and Its Mysteries. (Series II) New York: New York University Press, 90-107.

Doob, Leonard 1971. The Patterning of Time. New Haven: Yale University Press.

Efron, Robert 1990. The Decline and Fall of Hemispheric Specialization. Hillsville: Lawrence Erlbaum Associates.

Fischer, Roland (ed.) 1967. Interdisciplinary Perspectives of Time. (Annals of the New York Academy of Sciences. 138, Art. 2.) New York: Philosophical Libraries.

Fischer, Roland 1989. The time-like nature of mind: On mind functions as temporal patterns of the neural network. Diogenes 147: 5276. 
- 1990. Why the mind is not in the head but in the society's connectionist network. Diogenes 151/Fall: 1-27.

- 1992. A neuroepistomological view of natural and artificial intelligence: Reflections of evolved intelligence on intelligible aspects of its evolution. Cybernetica 35(3): 207-239.

- 1996. An individual mind is not an individual mind. Cybernetica 39(11): 513.

Fisher, B. Aubrey 1978. Perspectives on Human Communication. New York: Macmillan.

Fraisse, Paul 1963. The Psychology of Time. New York: Harper and Row.

Frank, Lawrence K. 1939. Time perspectives. Journal of Social Philosophy 4: 293-312.

Fraser, Julius T. (ed.) 1966. The Voices of Time. New York: George Braziller.

Freake, Douglas 1995. The semiotics of wristwatches. Time \& Society 4(1): 6790.

Freeman, Walter J. 1995. Societies of Brains: A Study in the Neuroscience of Love and Hate. Hillsdale: Lawrence Erlbaum Associates.

Gonseth, Ferdinand 1972. Time and Method: An Essay on the Methodology of Research. (trans. Guggenheimer, Eva H.), Springfield: Thomas.

Hall, Edward T. 1952. The Process of Change. Foreign Service Institute. United States Department of State, Washington, D.C.

- 1959. The Silent Language. Greenwich: Fawcett Publications.

- 1960. A microcultural analysis of time. In: Wallace, A. F. C. (ed.), Men and Cultures. Philadelphia: University of Pennsylvania Press, 118-122.

- 1966. The Hidden Dimension. Garden City: Doubleday Anchor Press.

- 1983. The Dance of Life: The Other Dimension of Time. Garden City: Doubleday Anchor Press.

Innis, Harold 1952. Changing Concepts of Time. Toronto: University of Toronto Press.

Isaacson, Robert L.; Pribram Karl H. (eds.) 1986. The Hippocampus, vol. 3. New York: Plenum Press.

Jibu, Mari; Hagan, S.; Hameroff, Stuart R.; Pribram, Karl H.; Yasue, Kunio. 1994. Quantum optical coherence in cytoskeletal microtubules: Implications for brain function. Biosystems 32: 195-209.

Jibu, Mari; Pribram, Karl H.; Yasue, Kunio 1996. From conscious experience to memory storage and retrieval: The rule of quantum brain dynamics and boson condensation of evanescent photons. International Journal of Modern Physics $B$ 10(13/14): 1735-1754.

KronoScope: Journal for the Study of Time (2001-). Boston: Brill Academic Publishers.

Kugelmass, I. Newton 1967. Foreword. In: Cohen, John (ed.), Psychological Time in Health and Disease. Springfield: Thomas, i-iv.

LeVay, Simon 1993. The Sexual Brain. Cambridge: The MIT Press.

Lomax, Alan 1982. The cross-cultural variation of rhythmic style. In: Davis, Martha (ed.), Interaction Rhythms: Periodicity in Communication Behavior. New York: Human Sciences Press, 149-174. 


\section{Thomas J. Bruneau}

Loy, R. 1986. Sexual dimorphism in the septohippocampal system. In: Isaacson, Robert L.; Pribram, Karl H. (eds.), The Hippocampus vol. 3. New York: Plenum Press, 301-332.

Maines, David R. 1987.The significance of temporality for the development of sociological theory. The Sociological Quarterly 28(3): 303-311.

Maxwell, Robert J. 1972. Anthropological perspectives. In: Yaker, Henri; Osmond, Humphry; Cheek, Francis (eds.), The Future of Time. Garden City: Doubleday, 36-72.

McGrath, Joseph E.; Kelly, Janice. R. 1986. Time and Human Interaction: Toward a Social Psychology of Time. New York: The Guilford Press.

McGrath, Joseph E.; Kelly, Janice. R. 1992. Temporal context and temporal patterning: Toward a time-centered perspective for social psychology. Time \& Society 1(3): 399-420.

McLuhan, Marshall 1964. Understanding Media: The Extensions of Man. New York: New American Library.

Merriam, Allen H. 1983. Comparative chronemics and international communication: American and Iranian perspectives on time. In: Bostrom, Robert (ed.), Communication Yearbook 7. New York: Sage Publications, 3548.

Moore, Wilber E. 1963. Man, Time and Society. New York: John Wiley.

Morello, Gabriele 1997. Research note: Sicilian time. Time \& Society 6(1): 55-69.

Mumford, Lewis 1962. Technics and Civilization. New York: Harcourt, Brace and World.

Nishimoto, Ikuko 1997. The 'civilization' of time: Japan and the adoption of the western time system. Time \& Society 6(2/3): 237-259.

O'Keefe, John; Nadel, Lyne 1978. The Hippocampus as a Cognitive Map. Oxford: Clarendon Press.

Pertierra, Raul 1993. Time and the local constitution of society: A northern Philippine example. Time \& Society 2(1): 29-50.

Polak, Frederik L. 1961. The Image of the Future, vol. 2. New York: Oceana.

Pribram, Karl H. 1971. Languages of the Brain: Experimental Paradoxes and Principles in Neuropsychology. Englewood Cliffs: Prentice-Hall.

- 1986. The cognitive revolution and mind/brain issues. American Psychologist 41(5): 507-520.

- 1990a. From metaphor to models: The use of analogy in neuropsychology. In: Leary, David E. (ed.), Metaphors in the History of Psychology. Cambridge: Cambridge University Press, 79-103.

- 1990b. Prolegomenon for a holonomic brain theory. In: Haken, Hermann; Stadler, Michael (eds.), Synergetics of Cognition, 45. Berlin: Springer-Verlag, $150-184$.

- 1991. Brain and Perception: Holonomy and Structure in Figural Processing. Hillsdale: Lawrence Erlbaum.

- 1993. Brain and the structure of narrative. In: Levine, Daniel S; Aparico, Manuel (eds.). Neural Networks for Knowledge, Representation and Inference. Hillsdale: Lawrence Erlbaum Associates, 375-417. 
- 1994. The variety of conscious experience: Biological roots and social usages. In: Carvallo, Marc E. (ed.), Nature, Cognition and System, vol. 3. Dordrecht: Kluwer Academic Publishers.

- 1996. Languages of the brain. (A psychology class) Center for Brain Research and Informational Sciences, Radford University Radford, VA.

- 1997. Brain and Perception. (A psychology class) Center for Brain Research and Informational Sciences, Radford University, Radford, VA.

- 1998. Brain and conscious experience. (A psychology class) Center for Brain Research and Informational Sciences, Radford University, Radford, VA.

- 1999. Brain and the composition of conscious experience. Journal of Consciousness Studies 6(5): 19-42.

- 2003. Forebrain psychophysiology of feelings, interest and involvement. International Journal of Psychophysiology 48: 115-131.

- 2004. Consciousness reassessed. Mind and Matter 2(1): 7-35.

Pribram, Karl H.; McGuinness, Diane 1992. Attention and para-attentional processing: Event-related brain potentials as tests of a model. In: Friedman, David; Brudder, Gerard E. (eds.), Psychophysiology and Experimental Psychopathology. (Annals of the New York Academy of Sciences, 658.) New York: Philosophical Libraries, 65-92.

Pribram, Karl H.; Bradley, Raymond T. 1998. The brain, the me, and the I. In: Ferrari, Michel; Sternberg R. J. (eds.) Self-Awareness: Its Nature and Development. New York: The Guilford Press, 273-307.

Priestly, J. B. 1964. Man and Time. New York: Dell.

Ricoeur, Paul 1984. Time and Narrative, vol. 1. Chicago: The University of Chicago Press.

- 1985. Time and Narrative, vol. 2. Chicago: The University of Chicago Press.

- 1988. Time and Narrative, vol. 3. Chicago: The University of Chicago Press.

Rogers, Everett M. 1962. Diffusion of Innovations. (1st ed.) New York: Free Press.

- 1983. Diffusion of Innovations. (3rd ed.) New York: Free Press.

- 1995. Diffusion of Innovations. (4rd ed.) New York: Free Press.

Rogers, Everett M.; Shoemaker, F. Floyd. 1971. Communication Innovations: A Cross-Cultural Approach. (2rd ed.) New York: Free Press.

Rogers, Everett M.; Kincaid, D. Lawrence 1981. Communication Networks: Toward a New Paradigm for Research. New York: Free Press.

Singhal, Avind; Law, S. 1997. A research agenda for diffusion of innovation scholars in the 21st century: A conversation with Everett M. Rogers. Journal of Developmental Communication 1(8): 39-47.

Time \& Society (1991-). Thousand Oaks: Sage Publications.

Varela, Francisco J.; Thompson, Evan; Rosch, Eleanor 1993. The Embodied Mind: Cognitive Science and Human Experience. Cambridge: The MIT Press.

Watzlawick, Paul; Beavin, Janet H.; Jackson, Don D. 1967. Pragmatics of Human Communication. New York: W. W. Norton.

Whitrow, Gerald T. 1972. What Is Time? London: Thames and Hudson.

Wright, Lawrence 1968. Clockwork Man: The Story of Time, Its Origins, Its Uses, Its Tyranny. New York: Horizon Press. 


\section{Thomas J. Bruneau}

Zerubavel, Eviatar 1979. Patterns of Time in Hospital Life. Chicago: University of Chicago Press.

- 1981. Hidden Rhythms: Schedules and Calendars in Social Life. Chicago: University of Chicago Press.

- 2003. Time Maps: Collective Memory and the Social Shape of the Past. Chicago: University of Chicago Press.

\section{Время, изменение и социокультурная коммуникация: хронемический подход}

Временные ориентиры являются основными составляющими ядерного идентитета каждой социокультурной группы. Способ, которым обычно выражаются прошлое (воспоминания), настоящее (перцепция) и будущее (ожидания, надежды), тесно связан с культурным идентитетом. Изменения в способах измерения времени и развитие объективных научных подходов к проблеме времени меняют и идентитет культуры.

На нашей планете существуют три основных модуса темпоральности (temporality): объективная, нарративная и трансцендентальная. Все эти три модуса связаны с разными мозговыми процессами. У объективной темпоральности наблюдается тенденция изменить традиционные нарративы и трансцендентальное (спиритуальное) время, временное членение (timing) и темпы. Объективное время соотносится со всем проходящим, настоящим и «прогрессивным». Объективное время само по себе является не традиционной формой культурного времени или продуктом культуры, а скорее изображением Запада в точных науках.

Настоящее эссе пытается представить новое понимание истоков семиозиса. Любая информация в своей сущности ритмична и передается нам сигналами по сенсорным путям в пространство-временном измерении, но затем сохраняется для дальнейшего употребления в спектральном термодинамическом измерении коры мозга.

Вся статья написана в «хронемическом» ключе, т.е. временность рассматривается с точки зрения семиотических процессов, связанных с человеческой коммуникацией. Такой подход можно считать новым как в теории коммуникации, так и в семиотике. 


\section{Aeg, muutus ja sotsiokultuuriline kommunikatsioon: kroneemiline lähenemine}

Ajalised orientiirid on iga sotsiokultuurilise üksuse tuumidentiteedi põhiliseks koostisosaks. Viis, kuidas minevikku (mälestusi), olevikku (taju) ja tulevikku (ootusi/lootusi) tavaliselt väljendatakse, on kultuurilise identiteediga tihedalt seotud. Aja mõõtmise viiside ning nendega seotud objektiivsete teaduslike ajakäsitluste arengumuutused muudavad ka kultuuri identiteeti.

Meie planeedil esineb kolm põhilist ajalisuse viisi: objektiivne, narratiivne ja transtsendentaalne. Kõik need kolm viisi on seotud erinevate protsessidega ajus. Objektiivsel ajalisusel on tendents traditsioonilisi narratiive ning transtsendentaalset (spirituaalset) aega, ajastust ja temposid muuta. Objektiivne aeg seostub kõige mööduva, modernse ja "progressiivsega". Objektiivne aeg ise ei ole kultuurilise aja traditsiooniline vorm ega kultuuriline saadus - pigem on ta Lääne täppisteaduslik kuvand. Käesolev essee püüab pakkuda uut arusaamist sellest, kuidas semioos tekib. Igasugune informatsioon on oma olemuselt rütmiline ning antakse meie sensoorseid juhteteid pidi signaalidena edasi ajalis-ruumilises alas, kuid seejärel talletatakse see edasiseks kasutamiseks ajukoore spektraalsesse termodünaamilisse alasse.

Kogu artikkel on kirjutatud "kroneemilise" lähenemise võtmes, see tähendab, et ajalisust käsitletakse inimsuhtlusega seonduvate semiootiliste protsesside pinnalt. Taolist lähenemist võib pidada uudseks nii kommunikatsiooni- kui semiootikauuringuis. 
